\title{
Candida flosculorum sp. nov. and Candida floris sp. nov., two yeast species associated with tropical flowers
}

Correspondence

Carlos A. Rosa

carlrosa@icb.ufmg.br

\author{
Carlos A. Rosa, ${ }^{1}$ Fernando C. Pagnocca, ${ }^{2}$ Marc-André Lachance, ${ }^{3}$ \\ Carla C. C. Ruivo, ${ }^{2}$ Adriana O. Medeiros, ${ }^{1}$ Mariana R. C. Pimentel, ${ }^{1}$ \\ Julio C. R. Fontenelle ${ }^{4}$ and Rogério P. Martins ${ }^{4}$ \\ ${ }^{1}$ Departamento de Microbiologia, ICB, C. P. 486, Universidade Federal de Minas Gerais, \\ Belo Horizonte, MG 31270-901, Brazil \\ ${ }^{2}$ Centro de Estudos de Insetos Sociais e Departamento de Bioquímica e Microbiologia, \\ Universidade Estadual Paulista - UNESP, C.P. 199, Rio Claro, SP 13506-900, Brazil \\ ${ }^{3}$ Department of Biology, University of Western Ontario, London, Ontario N6A 5B7, Canada \\ ${ }^{4}$ Departamento de Biologia Geral, ICB, C. P. 486, Universidade Federal de Minas Gerais, \\ Belo Horizonte, MG 31270-901, Brazil
}

\begin{abstract}
Two ascomycetous yeast species, Candida flosculorum sp. nov. and Candida floris sp. nov., were isolated from tropical flowers and their associated insects. C. flosculorum was isolated from flower bracts of Heliconia velloziana and Heliconia episcopalis (Heliconiaceae) collected from two Atlantic rain forest sites in Brazil. C. floris was isolated from flowers of Ipomoea sp. (Convolvulaceae) growing on the banks of the river Paraguai in the pantanal ecosystem in Brazil and from an adult of the stingless bee Trigona sp. and a flower of Merremia quinquefolia (Convolvulaceae) in Costa Rica. C. flosculorum belongs to the Metschnikowiaceae clade and C. floris belongs to the Starmerella clade. The type strain of $C$. flosculorum is UFMG-JL13 ${ }^{\top}(=\mathrm{CBS}$ $10566^{\top}=\mathrm{NRRL} Y-48258^{\top}$ ) and the type strain of C. floris is UWO(PS) 00-226.2 ${ }^{\top}(=\mathrm{CBS}$ $10593^{\top}=$ NRRL $\left.Y-48255^{\top}\right)$.
\end{abstract}

Flowers of plant species belonging to the Convolvulaceae and Heliconiaceae families are a rich source of novel yeast species. Most of the novel yeast species isolated from these plants belong to the Metschnikowia, Wickerhamiella and Starmerella clades. In ephemeral flowers of the Convolvulaceae, the yeasts are transported by pollinating and non-pollinating flies, beetles and bees that deposit them in the corolla. In the longer-lasting flowers of the Heliconiaceae, yeasts are probably introduced by a different and more diverse set of animal vectors and they may grow on the sugary compounds present in nectar (Lachance et al., 1998, 1999, 2001; Ruivo et al., 2006; Rosa et al., 2007).

In this paper, we describe two novel yeast species associated with flowers and related insects of these two plant families. The first species was found inhabiting flowers of Heliconia velloziana and Heliconia episcopalis in two Atlantic rain forest sites in Brazil. The second species was isolated from flowers of Ipomoea sp. on the banks of the river Paraguai,

The GenBank/EMBL/DDBJ accession numbers for the gene sequences of the D1/D2 domain of the 26S rDNA of strains UWO(PS) $00-226.2^{\top}$ and UFMG-JL13 ${ }^{\top}$ are AF313353 and EF137918, respectively.
Brazil, and from a stingless bee and a flower of Merremia quinquefolia (wood rose) in Costa Rica. Analysis of the sequences of the D1/D2 domains of the large-subunit rDNA showed that these species represent distinct species of the Metschnikowiaceae and Starmerella clades, respectively. These novel species are described as Candida flosculorum sp. nov. and Candida floris sp. nov.

The strains considered in this study are listed in Table 1. Two strains of $C$. flosculorum were isolated from nectar present in flower bracts of $H$. velloziana, collected in the Picinguaba area, an Atlantic rain forest site at the Serra do Mar state park in São Paulo state, in September 2000 (Ruivo et al., 2006). Five strains came from flower bracts of H. episcopalis in Parque Estadual do Rio Doce, an Atlantic rain forest in the state of Minas Gerais, collected in July 2002. Isolates of $C$. floris were obtained from flowers of Ipomoea sp. collected at the banks of the Paraguai river near the city of Corumbá, in the state of Mato Grosso do Sul, Brazil, in an area of pantanal ecosystem, in February 2002, and from a stingless bee (Trigona sp.) and a flower of M. quinquefolia collected in 2000 and 2001, respectively, in Santa Rosa National Park, Costa Rica. The yeasts were isolated on yeast extract-malt extract agar (YMA, 1\% 
Table 1. Sources of isolation of Candida flosculorum and Candida floris

UFMG, Universidade Federal de Minas Gerais, Brazil; CBS, Centraalbureau voor Schimmelcultures; UWO(PS), Yeast Culture Collection of the Department of Biology, University of Western Ontario, Canada.

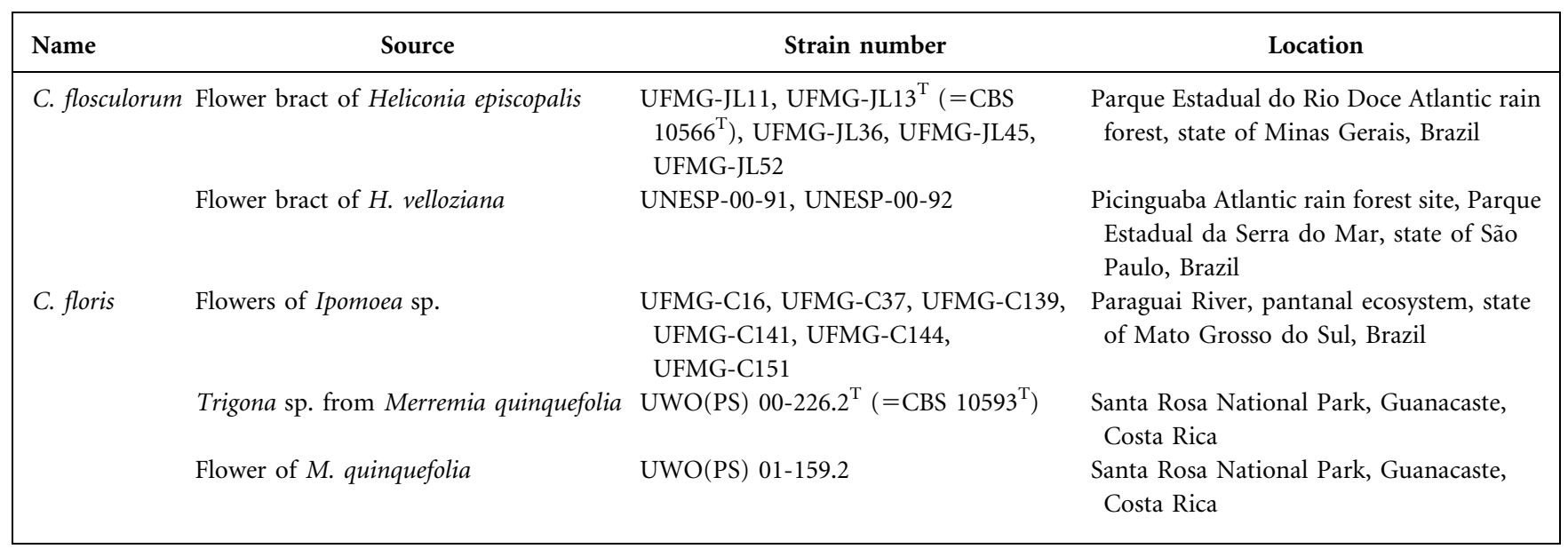

glucose, $0.5 \%$ peptone, $0.3 \%$ yeast extract, $0.3 \%$ malt extract and $2 \%$ agar) containing $100 \mathrm{mg}$ chloramphenicol $1^{-1}$. Sampling methods were as described previously (Lachance et al., 1998; Rosa et al., 2003; Ruivo et al., 2006). Plates were incubated at room temperature $\left(25 \pm 3{ }^{\circ} \mathrm{C}\right)$ for $3-8$ days. Each different yeast morphotype was purified and maintained on YMA slants or liquid nitrogen for later identification. The yeasts were characterized by standard methods (Yarrow, 1998). Identifications followed the keys of Kurtzman \& Fell (1998).

The D1/D2 variable domains of the large-subunit rDNA were amplified by PCR directly from whole cells as described previously (Lachance et al., 1999). The amplified DNA was concentrated and cleaned on QIAquick PCR columns (Qiagen) and sequenced using an ABI sequencer at the John P. Robarts Research Institute, London, Ontario, Canada. The sequence was edited with the program DNAMAN, version 6.0 (Lynnon BioSoft). Existing sequences for other related yeasts were retrieved from GenBank. The basic local alignment search tool (BLASTN) available at http://www.ncbi.nlm.nih.gov was used for this task. The CLUSTAL W software (Thompson et al., 1994) incorporated in DNAMAN was used to align the sequences and construct a neighbour-joining tree with 1000 bootstrap iterations.

\section{Species delineation, classification and ecology}

Candida flosculorum belongs to the Metschnikowiaceae clade and is phylogenetically related to Candida sp. BCC 7717, an undescribed species isolated from plant materials in Thailand (Fig. 1). These species showed more than $10 \%$ sequence divergence in the D1/D2 regions of the $26 \mathrm{~S}$ rDNA large-subunit. The sequences of the D1/D2 domains of three isolates of C. flosculorum (UFMG-JL13 ${ }^{\mathrm{T}}$, UFMG-JL52 and UNESP-00-92) were identical. All isolates of $C$. flosculorum had identical physiological profiles. C. flosculorum was isolated from two different Heliconia species and may be widely distributed in tropical rain forests. The Heliconia species sampled in our work occur in Southeastern Brazil and in Amazonia and H. episcopalis is also used as an ornamental plant in Florida, Hawaii and Costa Rica. Several insects, mainly species of Diptera, feed on the plant leaves and bracts and may be the most important vectors of this yeast. Several species of Merosargus (Diptera) use bracts and flowers of $H$. episcopalis for

\subsection{5}

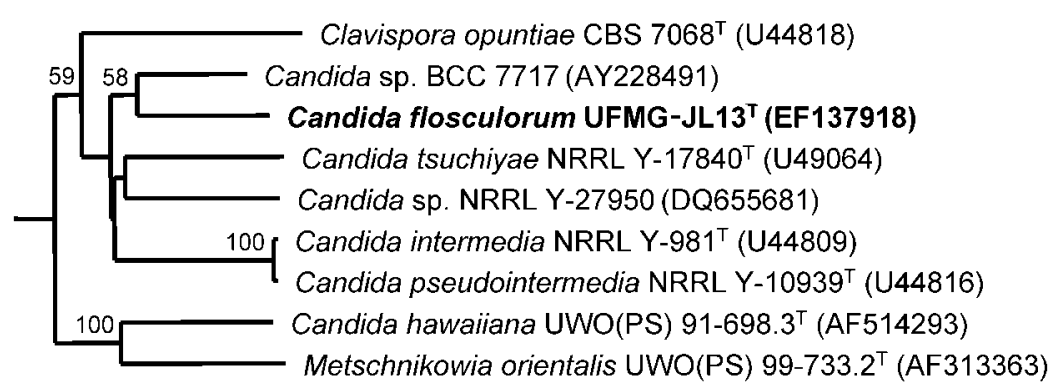

Fig. 1. Neighbour-joining tree showing the placement of Candida flosculorum among related species in the Metschnikowiaceae clade. Bootstrap values of $50 \%$ or above are shown. Bar, 0.05 substitutions per nucleotide position. 
feeding and breeding (J. C. R. Fontenelle, unpublished data). Other possible vectors of the yeast community associated with the nectar of Heliconia bracts are species of hummingbirds. In the Parque Estadual do Rio Doce, four species of hummingbirds are known to visit $H$. episcopalis flowers. These include Glaucis hirsuta and Phaethornis idaliae (A. C. F. Alves \& J. C. R. Fontenelle, unpublished data). Three other novel yeast species (Candida heliconiae, Candida picinguabensis and Candida saopaulonensis) were isolated from $H$. velloziana by Ruivo et al. (2006). This result suggests that Heliconia species may be an interesting yeast habitat that deserves further study.

Candida floris is related to Candida etschellsii, as these species showed $5.8 \%$ sequence divergence in the D1/D2 region of the rDNA large-subunit. Both species belong to the Starmerella clade (Fig. 2). Strain UWO(PS) 00-226. $2^{\mathrm{T}}$ differed by two substitutions in the D1/D2 region from the Brazilian strain UFMG-C151 (GenBank accession number EF679791). Our strains of $C$. floris were isolated directly from Convolvulaceae flowers and from a meliponine (stingless) bee captured on such a flower in Brazil and in Costa Rica. An association of $C$. floris with stingless bees that visit Convolvulaceae flowers is not unexpected as these insects are known to be an important source of yeast species in the Starmerella clade and are frequent visitors to these flowers. A mutually beneficial interaction may exist between them (Rosa et al., 2003; Pimentel et al., 2005).

Isolates of $C$. flosculorum and $C$. floris were examined after growth, individually or mixed in pairs, on several common sporulation media (cornmeal agar, dilute V8 agar, $5 \%$ malt extract agar and yeast carbon base agar supplemented with $0.01 \%$ ammonium sulphate, among others), but asci or signs of conjugation were not seen. These species probably occur in nature in the asexual form.

\section{Latin diagnosis of Candida flosculorum Rosa, Pagnocca, Lachance, Ruivo \& Medeiros sp. nov.}

In medio liquido post dies tres cellulae singulae aut binae; cellulae ovoidae $(2-3 \times 2-5 \mu \mathrm{m})$. Post unum mensem sedimentum formatur. Cultura in agaro malti post dies 14 $\left(17{ }^{\circ} \mathrm{C}\right)$ parva, convexa, glabra et candida. In agaro farinae Zea mays post dies 14 mycelium nec pseudomycelium non formantur. Glucosum fermentatur. Glucosum, sucrosum, maltosum, cellobiosum, melezitosum (lente), L-sorbosum, Dxylosum (lente), glycerolum, ribitolum, xylitolum, mannitolum, glucitolum, acidum succinicum, acidum citricum, 2keto-gluconatum assimilantur, at non galactosum, trehalosum, inulinum, raffinosum, melibiosum, lactosum, methyl $\alpha$-D-glucosidum, amylum solubile, L-rhamnosum, L-arabinosum, D-arabinosum, D-ribosum, ethanolum, methanolum, erythritolum, galactitolum, meso-inositolum, acidum lacticum, acidum gluconicum, glucosaminum, $N$-acetylglucosaminum, acetonum, ethyl acetas, nec hexadecanum. Ethylaminum, lysinum et cadaverinum assimilantur at non natrium nitricum nec natrium nitrosum. Ad crescentiuam vitaminae externae necessariae sunt. Augmentum in $37^{\circ} \mathrm{C}$. Habitat floris Heliconia episcopalis et $H$. velloziana in Brazil. Typus UFMG-JL13 ${ }^{\mathrm{T}}\left(=\mathrm{NRRL}\right.$ Y- $48258^{\mathrm{T}}=\mathrm{CBS} 10566^{\mathrm{T}}$ )

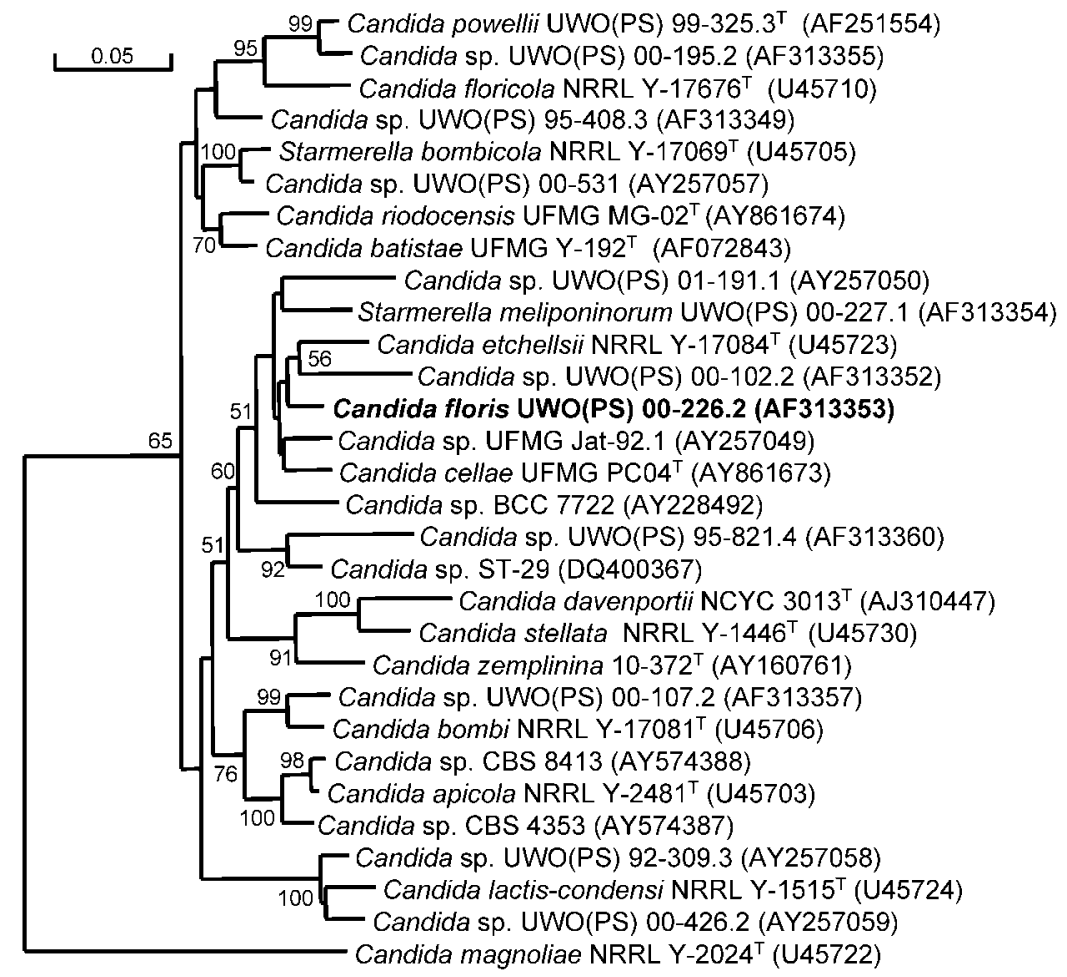

Fig. 2. Neighbour-joining tree showing the placement of Candida floris among related species in the Starmerella clade. Bootstrap values of $50 \%$ or above are shown. Bar, 0.05 substitutions per nucleotide position. 


\section{Description of Candida flosculorum Rosa, Pagnocca, Lachance, Ruivo \& Medeiros sp. nov.}

Candida flosculorum (flos.cu.lo'rum. L. gen. masc. pl. n. flosculorum of little flowers, refers to florets or flowers from where most of the strains were isolated).

In yeast extract-glucose broth $(0.5 \%: 2 \%, w / v)$ after 3 days at $25{ }^{\circ} \mathrm{C}$, the cells are ovoid to ellipsoidal (2$3 \times 2-5 \mu \mathrm{m}$ ). Budding is multilateral (Fig. 3a). A sediment is formed after a month, but no pellicle is observed. On YMA after 2 days at room temperature, colonies are white, convex, smooth and opalescent. In Dalmau plates after 2 weeks on cornmeal agar, pseudomycelia or true mycelia are not formed. Glucose is fermented. The following carbon compounds are assimilated: glucose, sucrose, maltose, L-sorbose, cellobiose, melezitose (slow), D-xylose, glycerol, salicin and xylitol. No growth occurs on galactose, trehalose, inulin, raffinose, melibiose, lactose, methyl $\alpha$-Dglucoside, soluble starch, L-rhamnose, D-arabinose, Larabinose, D-ribose, ribitol, ethanol, methanol, 2-propanol, 2-propanol, erythritol, galactitol, D-mannitol, D-glucitol, succinic acid, citric acid, lactic acid, gluconic acid, myoinositol, glucosamine, $\mathrm{N}$-acetylglucosamine, acetone, ethyl acetate or hexadecane. Assimilation of nitrogen compounds: positive for lysine, ethylamine- $\mathrm{HCl}$ and cadaverine and negative for nitrate and nitrite. Growth in vitamin-free medium is negative. Growth in amino-acid-free medium is positive. Growth at $37{ }^{\circ} \mathrm{C}$ is positive. Growth on YMA with $5 \%$ sodium chloride is positive, but negative at $10 \%$ sodium chloride. No growth in glucose-yeast extract broth $(50 \%: 0.5 \%, \mathrm{w} / \mathrm{v})$. Starch-like compounds are not produced. No growth with $1000 \mu \mathrm{g}$ cycloheximide $\mathrm{ml}^{-1}$. Urease activity is negative. Diazonium blue B reaction is negative. The habitat is flower bracts of Heliconia spp. in Brazil.

The type strain of Candida flosculorum, UFMG-JL13 ${ }^{\mathrm{T}}$ $\left(=\right.$ NRRL Y $-48258^{\mathrm{T}}=$ CBS $\left.10566^{\mathrm{T}}\right)$, was isolated from a flower bract of H. episcopalis in the state of Minas Gerais, Brazil.

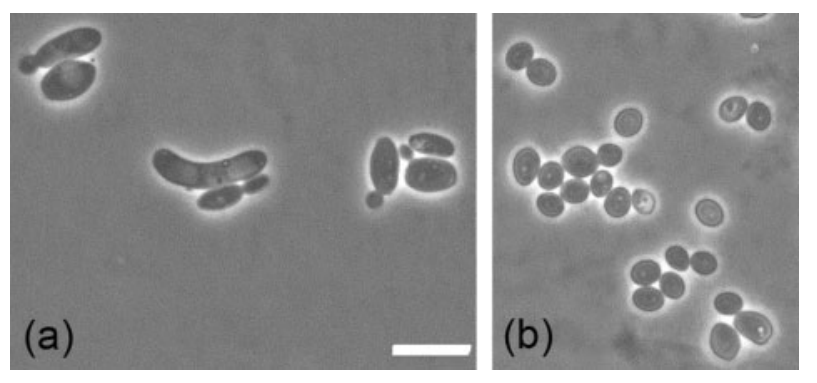

Fig. 3. Phase-contrast micrograph of budding cells of Candida flosculorum UFMG-JL13 ${ }^{\top}$ (a) and C. floris UWO(PS) 00-226.2 ${ }^{\top}$ (b) on yeast carbon base agar with $0.01 \%$ ammonium sulphate after 3 days at $22^{\circ} \mathrm{C}$. Bar, $5 \mu \mathrm{m}$.

\section{Latin diagnosis of Candida floris Rosa, Pagnocca \& Lachance sp. nov.}

In medio liquido post dies tres cellulae singulae aut binae; cellulae ovoidae $(2-3 \times 2-4 \mu \mathrm{m})$. Post unum mensem sedimentum formatur. Cultura in agaro malti post dies 14 $\left(17{ }^{\circ} \mathrm{C}\right)$ parva, convexa, glabra et candida. In agaro farinae Zea mays post dies 14 mycelium nec pseudomycelium non formantur. Glucosi fermentatio variabilis. Glucosum, galactosum, L-sorbosum, glycerolum (aliquando exigue), xylitolum (lente), mannitolum, glucitolum et acidum gluconicum assimilantur, at non sucrosum, trehalosum, maltosum, melezitosum, inulinum, raffinosum, melibiosum, lactosum, methyl $\alpha$-D-glucosidum, amylum solubile, cellobiosum, salicinum, D-xylosum, L-arabinosum, L-rhamnosum, D-arabinosum, D-ribosum, ethanolum, methanolum, erythritolum, galactitolum, ribitolum, meso-inositolum, acidum lacticum, acidum succinicum, acidum citricum, 2-keto-gluconatum, glucosaminum, $N$-acetylglucosaminum, xylitolum, acetonum, ethyl acetas, nec hexadecanum. Ethylaminum, lysinum et cadaverinum assimilantur at non natrium nitricum nec natrium nitrosum. Ad crescentiuam vitaminae externae necessariae sunt. Augmentum in $37^{\circ} \mathrm{C}$. Habitat floris in Brazil et Costa Rica. Typus UWO(PS) 00-226.2 ${ }^{\mathrm{T}}$ (=CBS $10593^{\mathrm{T}}=$ NRRL $\mathrm{Y}-48255^{\mathrm{T}}$ ).

\section{Description of Candida floris Rosa, Pagnocca \& Lachance sp. nov.}

Candida floris (flo.ris. L. gen. masc. n. floris of a flower, from where this yeast was isolated.

In yeast extract-glucose $(0.5 \%: 2 \%$, w/v $)$ broth after 3 days at $25{ }^{\circ} \mathrm{C}$, the cells are ovoid to ellipsoidal (2$3 \times 2-4 \mu \mathrm{m}$ ). Budding is multilateral (Fig. 3b). A sediment is formed after a month, but no pellicle is observed. On YMA after 2 days at room temperature, colonies are white, convex, smooth and opalescent. In Dalmau plates after 2 weeks on cornmeal agar, pseudomycelia or true mycelia are not formed. Glucose fermentation is variable. The following carbon compounds are assimilated: glucose, galactose (variable), L-sorbose (variable) glycerol (occasionally weak), D-mannitol, D-glucitol and D-gluconate. No growth occurs on inulin, raffinose, melibiose, sucrose, trehalose, maltose, lactose, melezitose, D-xylose, L-arabinose, ethanol, ribitol, xylitol, succinic acid, citric acid, methyl $\alpha$-D-glucoside, soluble starch, cellobiose, salicin, Lrhamnose, D-arabinose, D-ribose, methanol, 2-propanol, 2propanol, erythritol, galactitol, myo-inositol, lactic acid, glucosamine, $\mathrm{N}$-acetylglucosamine, acetone, ethyl acetate or hexadecane. Assimilation of nitrogen compounds: positive for lysine, ethylamine- $\mathrm{HCl}$ and cadaverine, and negative for nitrate and nitrite. Growth in vitamin-free medium is negative. Growth in amino-acid-free medium is positive. Growth at $37^{\circ} \mathrm{C}$ is positive. Growth on YMA with $10 \%$ sodium chloride is positive. Growth in yeast extractglucose $(0.5 \%: 50 \%$, w/v) broth is weak to strong. Starchlike compounds are not produced. Growth is positive in $1000 \mu \mathrm{g}$ cycloheximide $\mathrm{ml}^{-1}$. Urease activity is negative. 
Diazonium blue B reaction is negative. The habitat is flowers of Ipomoea sp. and M. quinquefolia in Brazil and Costa Rica.

The type strain of Candida floris, UWO(PS) $00-226.2^{\mathrm{T}}$ $\left(=\mathrm{CBS} 10593^{\mathrm{T}}=\mathrm{NRRL} \mathrm{Y}-48255^{\mathrm{T}}\right)$, was isolated from an adult of the stingless bee Trigona sp. from a M. quinquefolia flower in Costa Rica.

\section{Acknowledgements}

This work was funded by Conselho Nacional de Desenvolvimento Cientifico e Tecnológico-CNPq - Brazil (process no. 477528/03-1 and research fellowships for R.P.M., F. C.P. and C. A. R.), Fundação do Amparo a Pesquisa do Estado de Minas Gerais (FAPEMIG, process no. CBB-378/04), and the Natural Science and Engineering Research Council of Canada (M.-A. L.). We thank D. H. Janzen, the staff of the Santa Rosa National Park, the Government of Costa Rica, and funding from the National Science Foundation, USA (DHJ), for facilitating access to collection sites.

\section{References}

Kurtzman, C. P. \& Fell, J. W. (1998). The Yeasts: a Taxonomic Study, 4th edn. Amsterdam: Elsevier.

Lachance, M. A., Rosa, C. A., Starmer, W. T., Schlag-Edler, B., Barker, J. S. F. \& Bowles, J. M. (1998). Metschnikowia continentalis var. continentalis, Metschnikowia continentalis var. borealis, and Metschnikowia hibisci, new heterothallic haploid yeasts from ephemeral flowers and associated insects. Can J Microbiol 44, 279-288.
Lachance, M. A., Bowles, J. M., Starmer, W. T. \& Barker, J. S. F. (1999). Kodamaea kakaduensis and Candida tolerans, two new ascomycetous yeast species from Australian Hibiscus flowers. Can J Microbiol 45, 172-177.

Lachance, M. A., Starmer, W. T., Rosa, C. A., Bowles, J. M., Barker, J. S. \& Janzen, D. H. (2001). Biogeography of the yeasts of ephemeral flowers and their insects. FEMS Yeast Res 1, 1-8.

Pimentel, M. R. C., Antonini, Y., Martins, R. P., Lachance, M. A. \& Rosa, C. A. (2005). Candida riodocensis and Candida cellae, two new yeast species from the Starmerella clade associated with solitary bees in the Atlantic rain forest of Brazil. FEMS Yeast Res 5, 875-879.

Rosa, C. A., Lachance, M. A., Silva, J. O. C., Teixeira, A. C. P., Marini, M. M., Antonini, Y. \& Martins, R. P. (2003). Yeast communities associated with stingless bees. FEMS Yeast Res 4, 271-275.

Rosa, C. A., Lachance, M. A., Teixeira, L. C. R. S., Pimenta, R. P. \& Morais, P. B. (2007). Metschnikowia cerradonensis sp. nov., a yeast species isolated from ephemeral flowers and their nitidulid beetles in Brazil. Int J Syst Evol Microbiol 57, 161-165.

Ruivo, C. C. C., Lachance, M. A., Rosa, C. A., Bacci, M., Jr \& Pagnocca, F. C. (2006). Candida heliconiae sp. nov., Candida picinguabensis sp. nov., and Candida saopaulonensis sp. nov., three ascomycetous yeasts from Heliconia velloziana (Heliconiaceae). Int $J$ Syst Evol Microbiol 56, 1147-1151.

Thompson, J. D., Higgins, D. G. \& Gibson, T. J. (1994). ClustaL W: improving the sensitivity of progressive multiple sequence alignment through sequence weighting, position-specific gap penalties and weight matrix choice. Nucleic Acids Res 22, 4673-4680.

Yarrow, D. (1998). Methods for the isolation and identification of yeasts. In The Yeasts - a Taxonomic Study, 4th edn, pp. 77-100. Edited by C. P. Kurtzman \& J. W. Fell. Amsterdam: Elsevier. 